Our Nature (2004) 2:35-39

\title{
Fisheries Communities and Resource-Use Pattern: Chimdi Lake and its Surrounding Wetlands
}

\author{
Pramila Gachhadar $^{1}$, A. R. Adhikari ${ }^{2}$ \& R. P.Chaudhary ${ }^{3}$ \\ ${ }^{1}$ Everest Science Center, Biratnagar \\ ${ }^{2}$ Pro-public, Biratnagar \\ ${ }^{3}$ Central Department of Botany, Kirtipur, (T.U.) Kathmandu \\ E-mail: pramila_mp1998@hotmail.com
}

\begin{abstract}
The study was carried out among the fisheries dependent communities of Chimdi lake area, Sunsari district. Major stakeholders of fisheries communities in this lake and its surrounding areas, their expectations and role were identified.
\end{abstract}

Keywords: Chimdi lake, Fisheries Community, Wetlands, Sunsari district

\section{Introduction}

Chimdi lake is $12 \mathrm{~km}$ northwest from Biratnagar. It is also called as Barju Tal, which falls in Chimdi VDC of Sunsari district, eastern Nepal. In the past, this lake was one of the popular and richest wetland sites for surrounding vicinity. But the present scenario is totally different and the natural beauty doesn't exist there. Aquatic resources have already been extinct and remaining very few is at the verge of extinction. The loss of wetland habitat and convergence of lake system in agrarian is the major factor to bring this result.

Extinction of this wetland has already displaced some 200 fisheries family in search of other areas to sustain their occupation. Whereas some 250 households of potter community i.e., Pandits are still dependent on the soil of this lake.
Several workers (Shrestha 1992, Shrestha 1979, DFAMS 1985, Pradhan 1987) have studied fisherman status, fish farming, fish market in the country. Chimdi wetland and its surrounding areas have mixed composition over communities on its impact area. Mostly it and its surrounding areas are inhabited by ethnic communities of Tharu, Malaha ,Mooshar, etc, who lived in the area from centuries; whereas the rest groups are recent inhabitants.

\section{Social Figure}

Baseline survey shows that almost 150 households from Malaha commonly called as Godi, Mukhiya at Chimdi region are dependent upon this wetland. Major site for fishing for such community are Budhi river, Singhiya river, Chimdi lake. In summer, local fishermen invest fulltime in fishing rather than other seasons. 
Pramila Gachhadar, A. R. Adhikari \& R. P.Chaudhary / Our Nature (2004) 2:35-39

\section{Community Structure}

\section{Chimdi Village}

Total Population: 5711

Total Households: 1047

Male: 2823

Female: 2738

Illiterate: 2743

\section{Community Structure}

Thaur: $46.64 \%$

Mehata: $7.79 \%$

Sardar: $5.57 \%$

Governmental Land 117.3 hectors

Irrigated Area: 16.41 hectors

\section{Resource status}

\section{Name of Water Body}

Chimdi lake

Magar pond

Chhengra pokhari

Tengra pokhari

Budhi river

Canals and ditches

\section{Nature}

Degraded wetland

Fisheries activities

Polluted wetland

Natural wetland

River with permanent dam

Seasonal wetland

\section{$\underline{\text { Status }}$}

Restoration programs

Quatic weed encroachment

Waste disposal by sugar mill

Lacking management activity

Major habitat for aquatic diversity

Dereasing due to encroachment
Budhi river is only the permanent source of fisherman communities to some extent. With the extinction of Wetland areas (river, stream, lakes, pond) there is a greater risk towards the fisheries communities specially Malaha who has no alternative to their occupation on sustaining livelihood. Increasing population with high demand of resources is nowadays shrinking over limited wetlands. After launching the self-governance act 1998, the local authorities V.D.C, D.D.C have made their ownership over potential wetland sites, leased out on limited amount for contractor on collecting fish and harvesting resources as well. Fisherman community is being prevented to continue the traditional fishing occupation, which they have been conducting since long.

\section{Resource and their linkage with different stakeholders}

Fish resource linkage from the Chimdi and surrounding wetland can be observed from various leves of Stakeholder

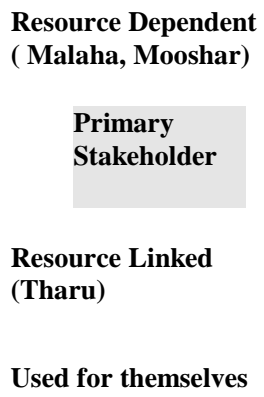

Used for themselves

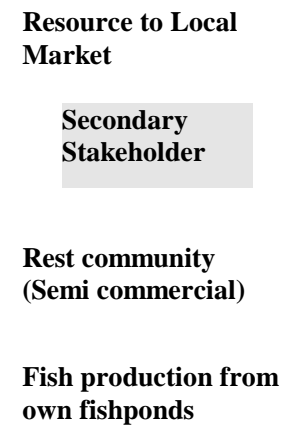

Contractor/ Businessman 
Small-scale collection of fishes to meet their livelihoods and house requirement are frequently done by the primary stakeholders mainly the Malaha, Tharu and Mooshar.

The way of using traditional methods are still providing the open space for regeneration. Rather than secondary and tertiary stakeholders the primary stakeholders understand well the linkage between environment and development.

i. Practical Approach on Conservation Effort at Chimdi Area

ii. Fish Catch Competition among various fisheries communities

Such competition was organized so as to gather the scattered knowledge among the diversity and status of local fishes found at Chimdi lake, especially from the disadvantaged groups. There was participation from the fisheries and deprived community like Malaha and Mooshar. Equally the popular fisheries community Tharus from the Chimdi and adjacent villages participated. The competition and prize distribution held there and an interaction and awareness program also took place simultaneously. Participant themselves identified the status of existing fish species. Almost 32 different species of fishes were identified by the contestants themselves and also accessed on their status at Chimdi lake at the current situation. They even assessed over the current practice of fishing and committed to apply some eco friendly manner so as to let the breeding fishes, rare fishes. They are also aware of banning the illegal practices like fish poisoning and electric fishing and committed to demoralize and check such practices. We found such contest as a wise practice of respecting any ones knowledge and inspiring themselves on conservation activities and biodiversity documentation as well. The concept of fish hunting is slightly changing. The fishermen are being interested in fish farming. Chimdi lake should focus on such deprived groups and their relevant activities.

\section{ii. Declaration made by participants of Interaction program within fisheries communities}

-Traditional fishermen who participated in the contest were mostly using the cast nets of suitable mesh sized that do not catch the small fishes.

-They were self-imposed for not catching fishes during the breeding time.

-Use locally available resources to trap fishes causing less damage and impact.

-Alteration of fish catches among various wetlands existing at Chimdi and its surrounding areas.

-Fishing limit is not to exceed from $2-3 \mathrm{~kg}$ per person each day.

\section{iii. A traditional way of fish catching}

They know that they can't afford to upset natural linkages between the resources and also that the sustainability of resources is important for their own livelihood and survival. Still the fisherman at Chimdi and its surrounding areas are using cast nets, Tegodia net, Chauki net, Pani net, Dip fishing net, and Balsi (Fish trapping hook) is also popular. Gaija, Khongi are the local basket implements of bamboo on collecting fish while fishing. All sorts of such Traditional practices are more or less eco friendly rather than the use of modern techniques applied on fish hunting.

\section{iv. Fish Market and Price at Chimdi Area \\ Hatiya (local market) is the centre for all the fishing communities. The fish products from the local areas are hardly sustaining 50\% of the total fish consumption and rest $30 \%$}


requirement is fulfilled by individuals' fishpond and lake. Only $20 \%$ of the catch fish is from the Natural sites like lake and streams.

\section{v.Fish Hunting or Fish farming}

Besides Malaha and Mooshar rest of fisheries and non-fisheries communities of Chimdi area is some how practicing fish farming on small scale by making ponds at their own land. But these groups are still almost depending upon the Natural resources. They are mostly engaged on collecting and selling the fishes from the contractor's and individuals fishpond. The concept of fish farming is not even set upon them because most of them lack sufficient land even for residential purposes since long. Fish hunting using traditional practices may be a vulnerable occupation for them. So there is an urgent need of technology transfer and engagement of these communities upon any conservation and utilization aspect of wetland management.

\section{vi. To be done for fish conservation at Chimdi Area}

-Involvement of deprived communities on fisheries development activities at Chimdi lake.

-The mesh size of fishnets used by the fisheries communities' standardizing so as to control over affecting the natural primary and secondary food chains.

-Stop collecting broods indiscriminately.

-Over fishing in general with no administrative controls.

vii. Expected asset for fisheries community of Chimdi and it's surrounding Area

-Technology transfer towards fisheries communities for sustainable fisheries program and secured access and rights on resource utilization and conservation.
-Involvement of such community on fisheries extension/development program at Chimdi.

-Employment opportunities and small-scale loan for the sake of searching new option emerging at Chimdi lake.

-Training /Awareness programs for human resource development.

-Initiatives for small scale research on fish fauna by the community themselves.

-Efforts of fisheries communities should timely be oriented towards the aquatic weed control at most of the wetlands they depend on.

\section{Conclusion}

A planned approach is required updating information on regular time interval: scientific team should monitor any activities at wetland sites and offer short term and long term management option considering the major attention over primary stakeholders of fisheries at Chimdi and its surrounding areas.

\section{Acknowledgements}

Authors thankfully acknowledge to Propublic (Forum for protection of public interest), Kathmandu / The Ford Foundation, for providing financial support. Thanks are due to all the villagers especially members of Public Property Development and conservation committee (PPDCC), Barju Tal and fishermen who helped during our study period at Chimdi V.D.C.

\section{References}

Pradhan, B.R. 1987. Potential of Reservoir Fishing Development in Nepal. In Proc. of a workshop on Reservior Fishing Management and Development in Asia, Kathmandu, IDRC, 264: p.29.

Shrestha, J. 1979. Water Resources and their utilization in Nepal. UNDP. In Water surface 
Pramila Gachhadar, A. R. Adhikari \& R. P.Chaudhary / Our Nature (2004) 2:35-39

management Training and seminar program. Shrestha, J. 1992. The role, scope \& importance of Natural Water Resources for increased fish production in Nepal. In Workshop IDRC/FDD,
April 1-3, 1992, Kathmandu. DFAMS 1985. Study on demand and supply of Fish in Kathmandu. Dep. of Food and Agricultural Marketing Services. Marketing Service Division, Patan. 